\title{
Alternative risk transfer in medium-sized and large companies: The case of Poland
}

\author{
Grzegorz Strupczewski \\ Department of Risk Management and Insurance, \\ College of Economics, Finance and Law, \\ Cracow University of Economics, \\ Poland \\ strupczg@uek.krakow.pl
}

Michat Thlon

Department of Economics, College of Economics, Finance and Law

Cracow, University of Economics,

Poland

thlonm@uek.krakow.pl

\author{
Alina Klonowska \\ Department of Risk Management and Insurance, College of \\ Economics, Finance and Law, Cracow University of Economics, \\ Poland \\ klonowsa@uek.krakow.pl
}

Abstract. The paper examines the application of alternative risk transfer (ART) in Poland. ART methods, enabling firms to transfer operational risks on capital markets, can be an interesting alternative to traditional insurance and reinsurance solutions, particularly in the catastrophic risk domain. Papers written to date on the ART subject have overwhelmingly focused on the West European and North American markets. Poland, as a post-communist country, can be an interesting example of an effective transformation of the national economy from socialism to capitalism. That's why the identification of factors that stay behind implementation of modern risk management strategies, such as ART, is a relevant issue. In our research, we have identified the key characteristics of enterprises using ART tools as part of their risk management policy. The empirical studies were based on the data derived from a survey questionnaire carried out on the representative sample of 642 medium-sized and large enterprises operating in Poland. The survey was conducted in 2017 on a sample of Polish medium-sized and large companies. A log-linear analysis was used to identify the features characterizing the enterprises that use modern ART

Received:

April, 2020

1st Revision:

March, 2021

Accepted:

May, 2021

DOI:

10.14254/2071$8330.2021 / 14-2 / 11$ 
tools to manage risk. Numerous factors determine which companies are more likely to apply ART, but the most relevant one is the company size (number of employees). Considering, no similar research has been conducted among Polish enterprises, the results of presented study may be recommended for further development of the domestic market for alternative risk-transfer instruments.

Keywords: alternative risk transfer, ART, insurance, risk management, corporate insurance.

\section{JEL Classification: G22, G32}

\section{INTRODUCTION}

Risk management is often defined as the decisions a company takes and the actions it carries out to achieve an acceptable level of risk (Bromiley et al., 2014). In practice, risk management involves diagnostic and risk-handling processes intend to stabilise financial performance and create conditions allowing the company to develop. The risk managment aimed to improve the companie's profitbility by oprimizing total cost of risk (Bertinetti, Cavezzali, \& Gardenal, 2013; Miciuła, 2015).

Risk management is a logically ordered series of consecutive events, actions, decisions, and agreements which result in the creation of a certain added value (Perera \& Holsomback, 2005; Fraser, Quail, \& Simkins, 2021). Over the years, risk management has evolved from a narrow insurance-based view to a holistic one commonly called Enterprise Risk Management (ERM) (Desender, 2011). ERM is intended to improve the company's performance and financial stability. Hence, the modern concept of integrated risk management, which is based on a holistic approach to risk in the context of a company's strategy and objectives, has grown increasingly more popular (Baxter, Bedard, Hoitash, \& Yezegel, 2012).

One of the areas ERM covers is catastrophe risk. In practice, it is difficult to cover catastrophic losses with an insurance policy, but alternative risk transfer (ART) methods can provide a solution. ART moves risk from the insurance market to the capital market by producing innovative products which combine insurance and capital markets (Banks, 2004). According to Culp (2002), ART products are contracts, structures or solutions provided by insurance or reinsurance companies that enable firms either to finance or transfer the risks to which they are exposed in a non-traditional way (i.e. other than insurance policy). The origins of ART can be traced back to enterprise risk management strategies seeking to reduce insurance premiums through risk retention. Growing exposure to risk retained via deductibles and coinsurance prompted the need to seek funds available when risk materializes. ART contains the following types of solutions (Punter, 2000): self-insurance, captive insurance company, finite re-/insurance (FiniteRe), multi-year/multi-line products (MMP), multi-trigger products (MTP), insurance-linked securities (ILS) ${ }^{1}$.

\footnotetext{
${ }^{1}$ Self-insurance can be done either in the form of balance sheet reserves or from emergency sources of external capital. FiniteRe can be an effective tool for securing high-risk exposure because it lowers insurance premium. It's a multi-year coverage enabling users to spread costs out over time. What makes it different from typical insurance is the refund of premium paid if there was no loss during insurance period (Myers, 1996). Captive insurance company is another ART solution that can act as a retention and risk transfer tool. Captive insurance company has a formalized structure of a typical insurance company but is set up and controlled by an entity (a sponsor) that is not related to the insurance sector. (Peace, 2008). ART also includes multi-year/multiline products (MMP) and multi-trigger products (MTP). With MMPs, multi-year insurance packages are developed, and the scope of their coverage can be individually tailored. The amounts of premium and maximum indemnity are predefined for the entire (multiyear) coverage period. This type of contract reduces transaction costs arising from the need to sign multiple policies and
} 
AON international broker reports that businesses have an increasing interest in ART (AON 2017; AON 2019). It is driven by emergence of new risks that are hard to cover by insurance industry at a reasonable price. Firms are seeking protection for the following risk classes:

- reshaping traditional operations as a result of the introduction of Industry 4.0;

- accelerated rates due tothe changes in market factors caused by mergers, acquisitions activities, regulations and new market entrants;

- commodity price volatility;

- protection of the value of intangible assets;

- transfer of large, complex risks (e.g. asbestos liability, environmental liability);

- new, hardly insurable risks (e.g. cyber risk, data breach, lack of "digital-ready" talents, political risk, terrorism risk);

- financial consequences of pandemic.

The ART market in Poland is at a very early stage of its development. Hence, there is a need to investigate the development potential of this market.

The novelty of the article is to identify the factors that lead enterprises in Poland to implement ART. Our research contributes to the existing literature as little has been published about the East-European market, particularly by using a cross-sectional sample of entities that operate in different industries. This paper is the first to examine the application of ART in Poland, a former communist satellite state that has rapidly modernised its economy and holds a dominant position within the CEE region. Research papers on the ART subject have overwhelmingly focused on the Western European and North American economies. Our research is based on a sample of 642 medium-sized and large corporations doing business in Poland, and that were surveyed by using the questionnaire of our own design. Then a log-linear model was built to identify the factors determining the firms' use of ART products.

The remainder of the paper is structured as follows. Sections 2 and 3 explicate the structure of the research sample, the diagnostic variables, and the procedure used to develop the statistical model. The next section discusses the research findings and the last section concludes.

\section{DETERMINANTS OF THE ART APPLICATION}

As literature regarding ART application is scarce, we took a broader perspective in our literature review by including ERM and financial hedging issues.

ensures that insurance costs remain fixed. Another benefit of MMPs is that they reduce the danger that a risk will be overlooked or that stand-alone insurance policies will overlap (Cummins, 2005). A supplementary trigger may be an external phenomenon independent of the cedent- e.g., a hurricane of a certain scale (Sigma, 2003). MTP contracts are very risky because in case of a catastrophic event, if only one trigger is faced, no indemnity would be paid (Matthews, 2005). Insurance-linked securities (ILS) are derivatives that allow a company to transfer catastrophic risk to capital markets. The most important ILS are catastrophe bonds, also known as cat bonds (the so-called Act of God Bonds). With cat bonds, the amount of a coupon earned by an investor and a return of the principal depend on sponsor's losses resulting from natural disasters or other extreme events. An entity that intends to transfer risk to capital market (i.e., to issue cat bonds) has to set up a Special Purpose Vehicle (SPV). The SPV issues cat bonds and sells them to investors. The capital collected from investors can be used by a sponsor to cover losses arising from a defined event (Lopez, 2006).derivatives that allow a company to transfer catastrophic risk to capital markets. The most important ILS are catastrophe bonds, also known as cat bonds (the so-called Act of God Bonds). With cat bonds, the amount of a coupon earned by an investor and a return of the principal depend on sponsor's losses resulting from natural disasters or other extreme events. An entity that intends to transfer risk to capital market (i.e., to issue cat bonds) has to set up a Special Purpose Vehicle (SPV). The SPV issues cat bonds and sells them to investors. The capital collected from investors can be used by a sponsor to cover losses arising from a defined event (Lopez, 2006). 
Financial theory offers several hypotheses to explain why corporations purchase hedging instruments and implement risk management procedures. Risk management including hedging can increase a firm's value by reducing (Haushalter, Heron, \& Lie, 2002; Mayers \& Smith, 1982, 1987; Mian, 1996; Nance, Smith, \& Smithson, 1993; Smith \& Stulz, 1985): the expected costs of financial distress, taxes, underinvestment and other agency costs. Risk aversion of the management is another reason for adoption of risk management (Smith \& Stulz, 1985). Numerous studies have been done on the determinants of Enterprise Risk Management. Unlike the traditional "silo-based" approach to corporate risk management, ERM enables firms to benefit from an integrated approach to managing risk that shifts the focus of the risk management function from primarily defensive to increasingly aggressive and strategic. Practice shows that ERM is adopted in order to comply with legal requirements and/or corporate governance. Xianbo, Bon-Gang \& Sui Pheng (2012) noted that these requirements arose from three sources: laws and regulations, non-mandatory reports and standards, and the rating agencies that included a company's ERM system in their rating methodology. The most commonly analysed determinants of ERM implementation include company-specific variables such as: company size, financial leverage, earnings volatility, stock price volatility, asset opacity, growth opportunity, diversification and institutional ownership (Gatzert \& Martin, 2015). An alternative approach would analyse seven variables that are closely related to ERM, including: a company's Chief Risk Officer (CRO), leverage, profitability, international diversification, institutional ownership, size, and turnover (Yazid, Razali, \& Hussin, 2012; Paape \& Speklé, 2012).Many empirical studies have proved that the size of a firm determines the use of hedging and enterprise risk management (Beasley, Clune, \& Hermanson, 2005; Geczy, Minton, \& Schrand, 1997; Liebenberg \& Hoyt, 2003; Mian, 1996; Sprčić \& Šević, 2012; Nance et al., 1993; Pagach \& Warr, 2011). Larger firms are more likely to hedge, which comes with substantial economies of scale but at significant cost. For many firms, the marginal benefits of a hedging programme may be exceeded by the marginal costs involved (Sprčić \& Šević, 2012). Another factor that may prompt a company to implement ART is leverage. According to Liebenberg and Hoyt (2003), more highly leveraged firms are more inclined to manage their risks. Minton and Schrand (1999) proved that firms engage in specific risk-management activity including ART to reduce the volatility that drives up the cost of accessing external capital. This means that the greater a company's leverage, the more likely it is to use RM. Geczy et al., (1997) reached a similar conclusion. In addition, they observed that firms with greater growth opportunities and tighter financial constraints are more likely to use derivatives as an RM instrument. Stulz (1984) noted that a firm's capital structure will affect its optimal hedging policy if the costs of financial distress are explicitly taken into account. Awareness of RM solutions is another factor that impacts hedging. Geczy et al., (1997) noted that the availability of many types of derivatives increases the likelihood a company will use hedging. Other proxies of RM awareness include the presence of CRO in a firm or a CEO's apparent support for ERM (Beasley et al., 2005; Fraser \& Simkins, 2010; Daud, 2011). Rosa (2006) highlights the qualities a successful CRO should have. Desender (2011), in turn, says that position of the CEO in the board has an important influence on the level of ERM adopted. Many studies have shown (Mian, 1996; Beasley et al., 2005; Liebenberg \& Hoyt, 2003) that whether or not ERM is implemented in an enterprise depends on the industry the enterprise operates in. Mian (1996) attributed this primarily to the fact that regulation differs by industry. He proved that regulated utilities are less likely to hedge than unregulated industries. Beasley et al. (2005) likewise showed that the industry in question is an important factor in determining the extent of ERM implementation. The banking, insurance and education sectors have the highest level of ERM sophistication.

Despite the relevance of determinants and the value of ERM, these issue have not been sufficiently or accurately studied with a focus on the European market using a cross-sectional sample of entities that operate in different industries. Having access to such studies would allow cross-industry differences 
regarding ERM implementation to be identified. The one exception would be Lechner and Gatzert (2016), whose research was the first to use a cross-sectional dataset for a European market in this context.

\section{RESEARCH METHODOLOGY}

The aim of this paper is to identify key features of enterprises that distinguish the ones that had implemented ART from the others. The following research hypotheses were verified empirically:

- H1. It is possible to identify features of enterprises that increase probability of implementation of ART.

- H2. The size of an enterprise (measured by number of employees) determines whether it will use alternative risk transfer techniques.

- H3. The size of an enterprise (measured by annual revenue) determines whether alternative risk transfer techniques will be used.

- H4. When management has had knowledge of ART methods, the chance that those methods will be used rises.

The data necessary to carry out the empirical study have been gathered using computer assisted telephone interviewing (CATI). The survey was conducted in 2017 on a sample of Polish medium-sized and large companies. The CATI survey has been based on a stratified random sample. In our case, the strata have been classified by type of business activity and the size of an enterprise. We contacted 1,821 entities and 642 of them conveyed complete data, so the resonse rate is $35.26 \%$.

In the present study, two measures are used as proxies for company size: annual turnover and number of employees. They will be measured in a simplified form as interval variables on an ordinal scale, because of limitations of the telephone interview we conducted (CATI). Moreover, we used the share of equity in total assets, which can be treated as a proxy for leverage (but with negative sign). We used this measure because it was easier for our respondents to answer a question about the share of equity in total assets than to specify the size of their company's leverage. This prompted us to examine whether factors such as leverage, the legal form of a company and the origin of equity (domestic or foreign) are associated with the use of ART. We believe that the legal form of a company can be a good variable to describe growth opportunities and access to equity financing.

The sample of 642 interviews reflects the industry structure of medium and large companies in Poland. We also assumed that the effective response rate should be $33 \%{ }^{2}$. We also assumed that if the above response rate had not been achieved, a supplementary survey would have been conducted, with correcting weights added as required. As the percentage of responses was higher than assumed, the sample was completed with the original assumptions.

Our questionnaire included questions about the respondent's knowledge of ART and the use of ART solutions (a dichotomous dependent variables). It also contains questions about selected descriptors of the enterprises surveyed such as:

- quantitative factors: number of employees, share of equity in the sum of assets, annual turnover, duration of business in years,

- qualitative factors: legal form of enterprise, prevailing form of ownership, the core business.

\footnotetext{
2 This level was assumed based on the results of annual Polish-wide research of the enterprise sector done by Polish Agency for Enterprise Development (PAED). In 2013, as a result of 16000 CATI interviews, response rate of 35\% was obtained (it was similar to the 2011 and 2012 editions). Major studies on Polish enterprises organized by PAED assume similar response rates in CATI research.
} 
Moreover, we added a variable to reflect the industry a company operates in. According to the official Polish classification of industries (PKD), there are 17 sections. We combined them into nine groups, considering the similarity of industries and minimal size of a group for statistical purposes. Finally, we obtained nine qualitative variables, either nominal or ordinal. The prevalence of qualitative data only together with the lack of quantitative variables made the use of classic measures and statistical tests impossible. Non-parametric statistical methods were therefore required. Table 1 presents a detailed description of our variables together with the possible variants of responses. Variants of responses for some questions have been aggregated to obtain the minimum required counts in each categories.

Table 1

Description of variables

\begin{tabular}{|l|l|l|}
\hline \multicolumn{1}{|c|}{$\begin{array}{c}|c| \\
\text { Variable }\end{array}$} & \multicolumn{1}{|c|}{ Variable description } & \multicolumn{1}{c|}{ Response options } \\
\hline ART & $\begin{array}{l}\text { Use of alternative risk transfer (a dependent } \\
\text { variable) }\end{array}$ & $\begin{array}{l}\text { (0) No } \\
\text { (1) Yes }\end{array}$ \\
\hline EMPL & Number of employees & $\begin{array}{l}\text { (1) } 50-250 \text { people } \\
\text { (2) More than 250 people }\end{array}$ \\
\hline EQUITY & The share of equity in the sum of assets & $\begin{array}{l}\text { (1) Up to } 50 \% \\
\text { (2) More than } 50 \%\end{array}$ \\
\hline FORM & Legal form of business & $\begin{array}{l}\text { (1) Partnership or sole proprietorship } \\
\text { (2) Capital company } \\
\text { (3) Other form }\end{array}$ \\
\hline KNOW_ART & Declared knowledge of ART & $\begin{array}{l}\text { (0) No } \\
\text { (1) Yes }\end{array}$ \\
\hline OWNERSHIP & $\begin{array}{l}\text { The prevailing form of ownership of } \\
\text { company capital }\end{array}$ & $\begin{array}{l}\text { (1) Principally Polish capital } \\
\text { (2) Principally foreign capital }\end{array}$ \\
\hline PKD & Company's scope of business (PKD section) & $\begin{array}{l}\text { (1) A; (2) B,D,E; (3) C; (4) F; (5) G; (6) H; (7) I,J; } \\
\text { (8) L,M,N; (9) P,Q,R,S }\end{array}$ \\
\hline TURNOVER & Company turnover in the last accounting & $\begin{array}{l}\text { (1) Less than 250 } \\
\text { (2) 250-2.500 } \\
\text { (3) 2.500-12.500 } \\
\text { (4) Over 12.500 }\end{array}$ \\
\hline year (in thousands USD) & $\begin{array}{l}\text { (1) Less than 10 } \\
\text { (2) 10-25 } \\
\text { (3) Over 25 }\end{array}$ \\
\hline
\end{tabular}

Source: Authors' calculations.

As a research tool was used a log-linear analysis, which enable to evaluate the dependences and interactions between the studied variables. In log-linear models, the counts in each cell are assumed to follow the Poisson distribution. In addition, the mean of the distribution in each cell is perhaps related to the classifying factors. The main goal of log-linear analysis is to find the smallest model that fits the data. The overall goodness-of-fit of a model is assessed by comparing the expected frequencies to the observed cell frequencies for each model. The goodness of fit of a log-linear model is usually tested using either the Pearson chi-square test statistic or the likelihood ratio statistic. The likelihood ratio can also be used to compare an overall model within a smaller, nested model (i.e. saturated model with one interaction or main effect dropped to assess the importance of that term) (Brzezińska 2013).

As already was said, our survey amounted for 642 respondents. $84 \%$ of them are representatives of medium-sized companies (up to 250 employees) and 16\% are from large enterprises (over 250 employees). 


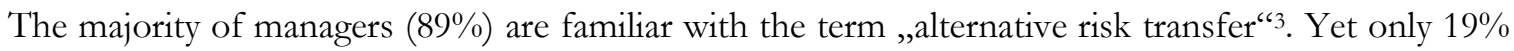
stated that they use ART techniques, with self-insurance the most frequently cited. $36 \%$ created their own protected cell within a mutual insurance company operating in Poland. The purchase of insurance coverage from a captive that has been set up for a company's own needs also proved to be a relatively popular solution (17\%). Similar share of respondents (approximately 12\% in each case) use the three other ART tools: finite risk insurance, ILS, and risk retention solutions. We also added a variable that accounts for an organisation's maturity. As some industry reports prove (e.g. AON 2017), the ability to implement ART - the most advanced risk financing technique - is directly linked with company's maturity. Based on our observation of Polish enterprises, we agree with that contention. We use the number of years the company has been doing business as a proxy for measuring its maturity. We think that the higher the likelihood of the firm employing ART instruments, the longer it has been in business. Coming back to the description of the sample, nearly half of the companies surveyed have been running their business for over 10 years (Fig. 1). The annual turnover of over half of respondents (55,9\%) exceeds USD 2,5 million (Fig. 2).

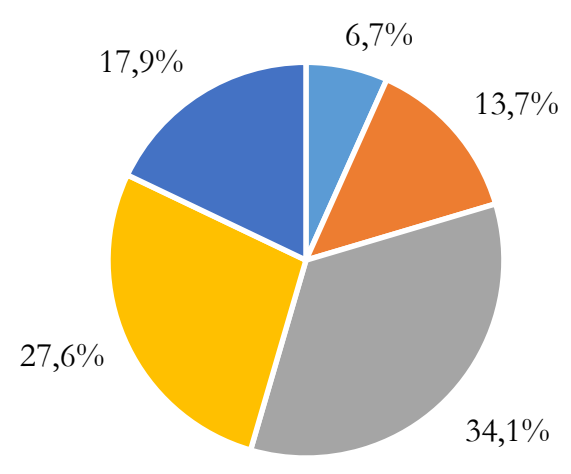

$\square$ Less than $2 \square 2-5$ years $\square 5-10$ years $\square 10-25$ years $\square$ More than 25

Figure 1. Number of years on the market Source: Authors' calculations.

\footnotetext{
${ }^{3}$ the question concerning the understanding of the concept of ART was an open question, the mere answer in the affirmative was not considered sufficient.
} 


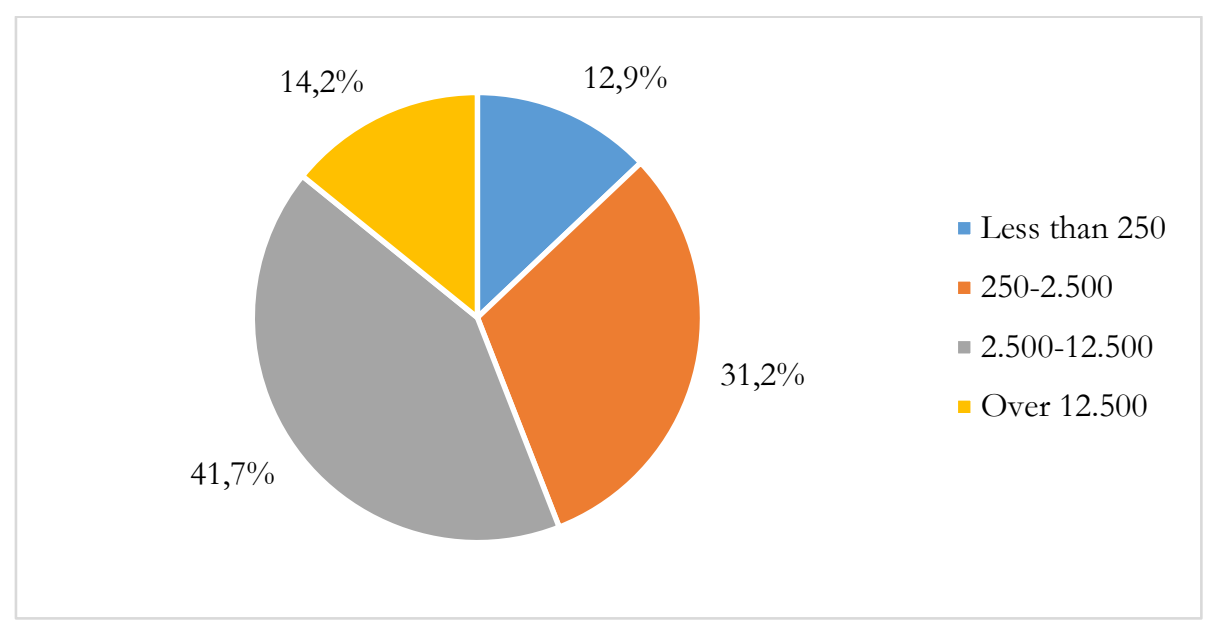

Figure 2. Turnover (in thousands USD)

Source: Authors' calculations.

\section{THE LOG-LINEAR MODEL}

The starting point of the statistical analysis is the pre-selection of variables obtained in the survey, with a view to rejecting those characteristics that are not significantly correlated with the dependent variable $A R T$. In other words, we eliminate those variables for which the significance test of the correlation coefficient showed that there are no grounds to reject the null hypothesis of the lack of correlation between each explanatory variable and variable $A R T$. Therefore, the nonparametric correlation coefficients, Kendall's (1975) tau-b and gamma, were calculated for all variables. Four variables with statistically significant ( $\mathrm{p}$-value $<0.05)$ Kendall's tau and gamma correlation coefficients (see Table 2) were chosen for further analysis. These include the following variables: KNOW_ART, EMPL, FORM, OWNERSHIP.

Table 2

Kendall's tau and gamma correlation with the variable ART

\begin{tabular}{|l|c|c|c|c|}
\hline \multicolumn{1}{|c|}{ Variables } & $\begin{array}{c}\text { Gamma } \\
\text { correlation }\end{array}$ & p-value for gamma & $\begin{array}{c}\text { Tau Kendall } \\
\text { correlation }\end{array}$ & $\begin{array}{c}\text { p-value for tau- } \\
\text { Kendall }\end{array}$ \\
\hline PKD & $-0,0646$ & 0,227773 & $-0,0318$ & 0,227773 \\
\hline KNOW_ART & 0,9026 & 0,000000 & 0,1614 & 0,000000 \\
\hline TURNOVER & 0,0337 & 0,554305 & 0,0156 & 0,554305 \\
\hline FORM & 0,2399 & 0,000097 & 0,1028 & 0,000097 \\
\hline EMPL & 0,9855 & 0,000000 & 0,4086 & 0,000000 \\
\hline YEARS & 0,0460 & 0,447257 & 0,0201 & 0,447257 \\
\hline EQUITY & $-0,1245$ & 0,072600 & $-0,0474$ & 0,072600 \\
\hline OWNERSHIP & $-0,1718$ & 0,002963 & $-0,0784$ & 0,002963 \\
\hline
\end{tabular}

Source: The authors.

Gamma and Kendall's tau correlation coefficients have similar signs for each variable, which is a positive sign showing the stability of inference. The strength of association between the use of ART and 
the various factors is not high. Only in one case does Kendall's tau exceed the absolute value of 0.40 . Other variables have correlation coefficients lower than $20 \%$.

Three of the chosen variables are stimulants (KNOW_ART, EMPL, FORM) and one variable is destimulant (OWNERSHIP). In order to simplify the notation, one-digit designations of variables have been adopted (Table 3).

Table 3

Designations of variables in the log-linear model

\begin{tabular}{|c|c|c|}
\hline Coding of variables & Variables & Number of variable categories \\
\hline 1 & OWNERSHIP & $\mathrm{a}=1,2$ \\
\hline 2 & FORM & $\mathrm{b}=1,2,3$ \\
\hline 3 & EMPL & $\mathrm{c}=1,2$ \\
\hline 4 & $K N O W_{-} A R T$ & $\mathrm{~d}=1,2$ \\
\hline 5 & $A R T$ & $\mathrm{e}=0,1$ \\
\hline
\end{tabular}

Source: Authors' calculations.

Construction of a log-linear model begins with a review of a table with simultaneous tests for all $\mathrm{k}$ term interactions (in this case $\mathrm{k}=5$ ). The test probability of the $\mathrm{p}$-value examines the significance of the incremental model. This means that we are attempting to determine whether the model expanded by adding an interaction is significantly different from the previous one. If so, it is assumed that the addition of the interaction significantly improves the fit of the model with the observed data (Table 4).

Table 4

Results of simultaneous tests forall k-term interactions

\begin{tabular}{|c|c|c|c|c|c|}
\hline $\begin{array}{c}\text { Degree of k-term } \\
\text { interactions }\end{array}$ & $\begin{array}{c}\text { Degree of } \\
\text { freedom }(\mathrm{df})\end{array}$ & $\begin{array}{c}\text { Maximum } \\
\text { Likelihood } \chi^{2} \\
\text { statistics }\end{array}$ & $\begin{array}{c}\text { p-value } \\
\text { for ML }\end{array}$ & $\begin{array}{c}\text { Pearson's } \chi^{2} \\
\text { statistics }\end{array}$ & $\begin{array}{c}\text { p-value } \\
\text { for Pearson }\end{array}$ \\
\hline 1 & 6 & 1645,538 & 0,0000 & 3032,183 & 0,0000 \\
\hline 2 & 14 & 132,675 & 0,0000 & 310,435 & 0,0000 \\
\hline 3 & 16 & 21,967 & 0,1443 & 24,284 & 0,0835 \\
\hline 4 & 9 & 4,676 & 0,8616 & 5,309 & 0,8066 \\
\hline 5 & 2 & 1,075 & 0,5841 & 1,140 & 0,5654 \\
\hline
\end{tabular}

Source: Authors' calculations.

The first row of Table 4, which lists the main effects without interaction, shows that the null hypothesis dealing with the independence of factors $(\mathrm{p}<0.00001)$ must be rejected. Thus, it can be said that the analysed frequencies vary depending on the levels of the terms. The model without two-way interactions must also be rejected ( $\mathrm{p}<0.00001$ in the second row of the table). Thus, including in the model all interactions of the second order improves the fit, which cannot be said for the model extended with interactions of the third order $(\mathrm{k}=3)$, since $\mathrm{p}=0.8066$.

In conclusion, the least complex model to match the frequency table is one with two-way interactions. The decision of which two-way interactions are to be included in the log-linear model is facilitated by analysis of the data contained in the table 5 of partial and marginal effects.

Partial dependence shows whether a corresponding interaction is important, when all the other effects of the same level are already in the model. With marginal effects, boundary dependence is a comparison of the model without any interaction of the second order with the model that takes into 
account the interaction being considered. Thus, it indicates whether the appropriate interaction has an effect when the model does not yet contain interactions of the same order (Stanisz, 2007).

Table 5

Tests of marginal and partial effects

\begin{tabular}{|c|c|c|c|c|c|}
\hline \multirow{2}{*}{ Effect } & \multirow{2}{*}{$\begin{array}{c}\text { Degrees of } \\
\text { freedom }(\mathrm{df})\end{array}$} & \multicolumn{2}{|c|}{ Partial effects } & \multicolumn{2}{c|}{ Marginal effects } \\
\cline { 3 - 6 } & & $\chi^{2}$ statistics & $p$-value & $\chi^{2}$ statistics & $p$-value \\
\hline 1 & 1 & 117,900 & 0,0000 & 117,900 & 0,0000 \\
\hline 2 & 2 & 233,830 & 0,0000 & 233,830 & 0,0000 \\
\hline 3 & 1 & 626,259 & 0,0000 & 626,259 & 0,0000 \\
\hline 4 & 1 & 418,503 & 0,0000 & 418,503 & 0,0000 \\
\hline 5 & 1 & 249,046 & 0,0000 & 249,046 & 0,0000 \\
\hline 12 & 2 & 6,522 & 0,0384 & 4,101 & 0,1287 \\
\hline 13 & 1 & 7,178 & 0,0074 & 3,824 & 0,0505 \\
\hline 14 & 1 & 0,142 & 0,7064 & 0,375 & 0,5405 \\
\hline 15 & 1 & 0,814 & 0,3670 & 0,031 & 0,8608 \\
\hline 23 & 2 & 25,137 & 0,0000 & 30,232 & 0,0000 \\
\hline 24 & 2 & 0,609 & 0,7376 & 0,778 & 0,6777 \\
\hline 25 & 2 & 0,960 & 0,6189 & 9,045 & 0,0109 \\
\hline 34 & 1 & 4,378 & 0,0364 & 0,273 & 0,6011 \\
\hline 35 & 1 & 71,373 & 0,0000 & 74,127 & 0,0000 \\
\hline 45 & 1 & 14,085 & 0,0002 & 10,296 & 0,0013 \\
\hline
\end{tabular}

Source: Authors' calculations.

The effects for which partial and marginal dependencies are statistically significant $(p<0.05)$ should be included in the model, because they improve its fit to the empirical data. Taking into account only the interactions of the first and second order (as a result of the foregoing analysis), the model will include the relationships between:

- OWNERSHIP and EMPL - effect 13,

- FORM and EMPL - effect 23,

- EMPL and $A R T$ - effect 35,

- KNOW_ART and $A R T$ - effect 45 .

The aim of the study is to identify the variables that affect the decision of a company to apply alternative risk transfer (ART) techniques, so the relationship of variable 5 (ART) with all other variables will be of our interest. The interactions between the explanatory variables (effects 13 and 23) are outside our area of interest. However, since removing them from the model could adversely affect its fit, the model will include the effect representing all the relationships between the explanatory variables (i.e. effect 1234) (Stanisz, 2007).

Finally, the log-linear model will include the following effects: 35, 45, 1234.

Written as an additive function, the formula is as follows:

$\ln \left(n_{\text {abcde }}\right)=\mu+\lambda^{1}+\lambda^{2}+\lambda^{3}+\lambda^{4}+\lambda^{5}+\lambda^{12}+\lambda^{13}+\lambda^{14}+\lambda^{23}+\lambda^{24}+\lambda^{34}+\lambda^{35}+\lambda^{45}+\lambda^{123}+\lambda^{134}+\lambda^{234}+\lambda^{1234}$

where: 
$\mu$ is the mean of natural logarithms of partial numbers in the contingency table, $\lambda^{X Y}$ is the impact for relationships of variables $X$ and $Y$.

The measures of goodness of fit presented in Table 6 allow us to conclude that the model satisfactorily explains the frequencies in the multi-way table.

Table 6

Measures of goodness of fit

\begin{tabular}{|l|c|c|c|}
\hline \multicolumn{1}{|c|}{ Test } & Statistics $\chi^{2}$ & Degrees of freedom & $p$-value \\
\hline Chi-square of maximum likelihood & 11,96707 & 21 & 0,9405 \\
\hline Pearson's chi-square & 13,35405 & 21 & 0,8957 \\
\hline
\end{tabular}

Source: Authors' calculations. Another way to assess the goodness of fit of a model is to evaluate a scatter plot of the observed values relative to the fitted values (Fig. 3).

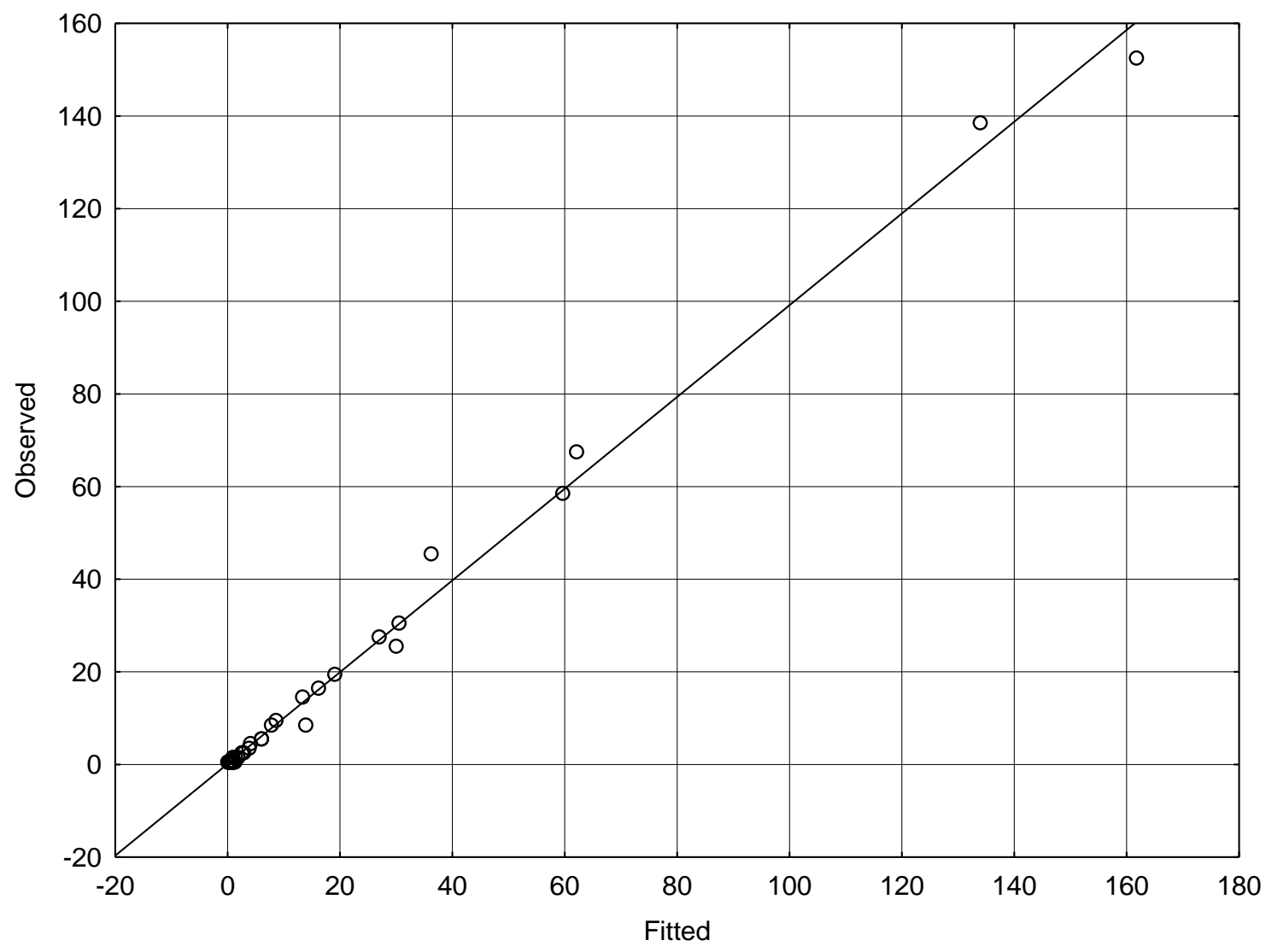

Figure 3. Scatter plot of observed values versus fitted values

Source: Authors' calculations.

Most of the points in the plot are arranged along the straight line. It confirms the good quality of the model and the absence of outliers.

The analysis proved two important relationships:

- between size of employment in a company (EMPL) and use of ART,

- between knowledge of ART declared by the management (KNOW_ART) and use of ART. 
For a more detailed interpretation of the nature of these relationships, we analyzed marginal distributions of variables (Table 7).

Table 7

Marginal distributions of variables

\begin{tabular}{|c|c|c|c|c|c|c|}
\hline Variables & \multicolumn{3}{|c|}{ EMPL } & \multicolumn{3}{c|}{ KNOW_ART } \\
\hline ART & 1 & 2 & Total & 0 & 1 & Total \\
\hline 0 & 523 & 7 & 530 & 77 & 453 & 530 \\
\hline 1 & 104 & 32 & 136 & 7 & 129 & 136 \\
\hline Total & 627 & 39 & 666 & 84 & 582 & 666 \\
\hline
\end{tabular}

Source: Authors' calculations.

The odds ratio for the relationship between variables $A R T$ and EMPL is 22.99. It means that the odds of a large company using ART are almost 23 times greater than those in an medium-size enterprise. In the case of the second of the identified relationships, the odds of implementing $A R T$ solutions increase by about three times $(\mathrm{OR}=3.13)$ if the shareholders or the management of the company have any knowledge of alternative methods of risk financing and risk transfer. This shows the importance of training and proper information policy in raising awareness among stakeholders and the demand for innovative solutions in the area of risk management.

\section{DISCUSSION}

The research methods applied have enabled the verification of the research hypotheses. The first hypothesis - that it is possible to identify features of enterprises that increase probability of ART implementation - has been positively verified. As our research shows, it is more probable that companies with more employees will apply ART. We calculated the correlation between variables such us: legal form of business and number of employees. These variables were statistically significant, which means that it is possible to mark features which determine the likelihood that ART will be implemented. In addition to those, there are variables which are negatively correlated, including the company's scope of business.

The empirical findings reported in the literature on the impact of some variables on ERM implementation by enterprises are mixed and often even contradictory. Some studies have identified enterprise size as a significant factor (Colquitt, Hoyt, \& Lee, 1999, Beasley et al., 2005; Pagach \& War, 2011) while Liebenberg and Hoyt (2003) found it to be non-explanatory. Our second hypothesis - that the size of enterprise (employment) determines the odds of use of ART - has been confirmed. Companies that employ more than 250 employees are 23 times more likely to use ART solutions than smaller companies are. According to Gatzert and Martin (2015), in their research based on data from American companies, as well as Lechner and Gatzert (2016), in their research on German companies, company size plays a role in the decision to employ risk management strategy. It is also a significant factor in Poland. The third hypothesis - that the value of annual turnover is a factor increasing odds of ART application in a firm - did not hold up in the light of empirical study. According to our model, company turnover does not have a statistically significant relation with the decision to use ART. In companies where the annual turnover exceeds USD 2.5 million, there is no evidence for greater use of ART. However, Beasley, Branson, Hancock (2016) showed that half of the largest organisations in the US with revenues greater than USD 1 billion have complete ERM processes in place. The fourth hypothesis assumed that when the management has knowledge of ART, the chance that those methods will be used rises, has been also 
confirmed. We measured awareness of ART by directly asking whether the respondent is competent in ART. When managers are aware of ART methods, they are three times more likely to implement them in their firms.

\section{RESULTS}

In Poland, alternative risk transfer has not yet become a widely used risk management technique. In our sample, ART was more frequently applied in large enterprises $(79 \%)$ than in medium-sized firms $(21 \%)$.

Our research identified the most important characteristics that distinguish companies that apply ART tools from those that do not. The results show that the strength of the relationship between the use of ART and legal form of business is not high. Most variables have correlation coefficients lower than $20 \%$ (either in plus or in minus). One exception is employment (EMPL), where the correlation coefficient is about $40 \%$. This demonstrates the complexity of the issues related to using ART in enterprise strategy and proves that a final decision on its implementation is influenced by many factors. The size of the company is dominant. The majority of the variables analysed here tend to increase the likelihood that ART will be implemented. There are also three destimulants of ART: company's scope of business, the share of equity in the sum of assets and the prevailing form of ownership of the company's capital. The companies using ART have a preponderance of Polish capital in equity and the possession of a less than $50 \%$ share of equity in total assets. That is, they were less leveraged.

\section{CONCLUSION}

To our best knowledge, empirical research on factors determining the use of ART by firms are almost absent. In order to fill this research gap, we started from review of existing theory on ERM and financial hedging, and from investigation of results of empirical studies on this topic. Our preliminary assumption was that the determinants of ART application are similar to those proved to be relevant in ERM choice, as they both belong to the risk management domain. We analyzed 642 Polish MLEs and we examined what features of the companies and their management are associated with the use of ART solutions. Our research was conducted on the basis of data collected through the CATI survey. It limited the amount of information we were able to gather, as well as our ability to draw more specific conclusions. In particular, we weren't able to use broader data from financial statements of the surveyed companies because our respondents were anonymous.

We conclude that decision to apply ART is conditioned by firm size in terms of employment. Bigger companies are more prone to transfer and finance risk via alternative solutions, what can be explained by economies of scale. ART demands sophisticated knowledge and this proved to be the second important factor of the ART choice. If company managers understand how ART solutions work, it is more probable that they will implement them into corporate risk management policy.

As a post-communist country, Poland is an interesting example of effective transformation of the economy. In this context, identyfing factors that stay behind implementation of modern risk management strategies, such as ART, is an relevant issue for policymakers and academics. Future research should address two issues. First, the causes underlying the decision to use ART. Secondly, whether enterprises treat these techniques as a cost effective way of balancing insurability. Another perspective for future research is to adjust the questions asked to managers to try to spot behavioral aspects of risk-related decisions. Undoubtedly, future research should be based on an international comparison of the ART practices of MLEs. 
Given the importance of MLEs in the Polish economy, as in other countries around the world, it is extremely important to continue studying their decisions, also with regard to risk transfer. Mitigation of risks faced by MLEs protects not only them, but also the national economy as the whole.

Due to the similar level of development of the ART market, in the authors' opinion, the results may also be applied to other countries in Central and Eastern Europe (countries that have undergone system transformation)

\section{ACKNOWLEDGEMENT}

This project was financed by the Ministry of Science and Higher Education within the 'Regional Initiative of Excellence 'Program for 2019-2022. Project no.: 021 / RID / 2018/19.

\section{REFERENCES}

AON. (2017). Global Risk Management Survey 2017. Retrieved from http://www.aon.com/2017-global-riskmanagement-survey/pdfs/2017-Aon-Global-Risk Management-Survey-Full-Report-062617.pdf

AON. (2019). Global Risk Management Survey 2019. Retrieved from https://www.aon.com/2019-top-global-risksmanagement-economics-geopolitics-brand-damage-insights/index.html.

Banks, E. (2004). Alternative risk transfer. Integrated risk management through insurance, reinsurance, and the capital markets. Chichester: John Wiley \& Sons Publ.

Baxter, R., Bedard, J. C., Hoitash R., \& Yezegel, A. (2012). Enterprise Risk Management Program Quality: Determinants, Value Relevance and the Financial Crisis. Contemporary Accounting Research, 30(4), 1264-1295. doi.org/10.1111/j.1911-3846.2012.01194.x.

Beasley, M. S., Clune, R., \& Hermanson, D. R. (2005). Enterprise risk management: an empirical analysis of factors associated with the extent of implementation. Journal of Accounting and Public Policy, 24(1), 521-531. doi:10.1016/j.jaccpubpol.2005.10.001.

Belás, J., Bartoš, P., Ključnikov, A., Doležal, J. (2015). Risk perception differences between micro-, small and medium enterprises, Journal of International Studies, 8(3), 20-30. doi: 10.14254/2071-8330.2015/8-3/2.

Bertinetti, G. S., Cavezzali, E., \& Gardenal G. (2013). The effect of the enterprise risk management implementation on the firm value of European companies, Working paper 10/2013, Department of Management, Università Ca' Foscari Venezia. Retrieved from http://ideas.repec.org/p/vnm/wpdman/46.html.

Bromiley, P., McShane, M., Nair, A., \& Rustambekov, E. (2015). Enterprise risk management: Review, critique, and research directions. Long range planning, 48(4), 265-276.

Brzezińska, J. (2013). Model selection methods in log-linear analysis. Acta Universitatis Lodziensis. Folia Oeconomica, 285, 107-114.

Colquitt, L. L., Hoyt, R. E., \& Lee, R. B. (1999). Integrated risk management and the role of the risk manager, Risk Management and Insurance Review, 2(3), 43-61. Retrieved from https://doi.org/10.1111/j.15406296.1999.tb00003.x

Culp, C. L. (2002). The ART of risk management: alternative risk transfer, capital structure, and the convergence of insurance and capital markets. Vol. 142. John Wiley \& Sons.

Cummins, J. D. (2005). Convergence in wholesale financial services: Reinsurance and investment banking, The Geneva Papers, The international association for the study of insurance economics, Geneva. doi:10.1057/palgrave.gpp.2510031.

Cummins, J. D. (2007). Innovations in alternative risk transfer: capital market and insurance market solutions. Paper presented at the Temple University SCOR-JRI Conference, 20 September.

Daud, W. N. W. (2011). The Role of the Quality Internal Adult Support in Enterprise Risk Management (ERM) Practices: Evidence from Malaysia. International Journal of Business and Social Science, 2 (5). 
Desender, K. (2011). On the Determinants of Enterprise Risk Management Implementation. In: Enterprise IT Governance, Business Value and Performance Measurement, edited by N. Si Shi and G. Silvius. IGI Global (1). doi: 10.4018/978-1-60566-346-3.ch007.

Fraser, J., \& Simkins, B. J. (2010). Enterprise risk management. Today's leading research and best practices for tomorrow's executives. New Jersey: John Wiley and Sons.

Fraser, J. R. S., Quail, R., Simkins, B. J. (2021) Questions that are asked about enterprise risk management by risk practitioners, Business Horizons, Available online 25 February 2021, In Press, Journal Pre-proof, https://doi.org/10.1016/j.bushor.2021.02.046

Gatzert, N., \& Martin, M. (2015). Determinants and value of enterprise risk management: empirical evidence from the literature, Risk Management and Insurance Review, 18(1), 29-53. doi.org/10.1111/rmir.12028

Geczy, C. B., Minton, A., \& Schrand, C. (1997). Why Firms Use Currency Derivatives, The Journal of Finance 52(4): 1323-1354. Retrieved from http:/ /links.jstor.org/sici?sici=00221082\%28199709\%2952\%3A4\%3C1323\%3AWFUCD\%3E2.0.CO \%3B2I

Haushalter, G. D., Heron, R. A., \& Lie, E. (2002). Price Uncertainty and Corporate Value, Journal of Corporate inance: Contracting, Governance and Organization 8 (3), 271-286. doi: 10.1016/S0929-1199(01)00043-8.

Hoyt, R. E., \& Liebenberg, A. P. (2011). The Value of Enterprise Risk Management. The Journal of Risk and Insurance, 78 (4). doi.org/10.1111/j.1539-6975.2011.01413.x

Kendall, M. G. (1975). Rank Correlation Methods. London: Charles Griffin \& Co. Limited.

Lechner, P., \& Gatzert, N. (2016). Determinants and Value of Enterprise Risk Management: Empirical Evidence from Germany. Retrieved from https://papers.ssrn.com/sol3/papers.cfm?abstract_id=2735050.

Liebenberg, A. P., \& Hoyt, R. E. (2003). The Determinants of Enterprise Risk Management: Evidence from the Appointment of Chief Risk Officers, Risk Management and Insurance Review 6 (1), 37-52. Retrieved from https://doi.org/10.1111/1098-1616.00019

Lopez, C., B. (2006). Pricing Catastrophic Bonds for Earthquakes in Mexico, Berlin: Humboldt University.

Matthews, M. (2005). The ART of managing hedge fund risk, Finance Magazine. Retrieved from http://www.financeagazine.com/display_article.php?i=5404\&pi=142.

Mayers, D., \& Smith, C. (1982). On the corporate demand for insurance, The Journal of Business 55(2), 281-296. http://dx.doi.org/10.1086/296165.

Mayers, D., \& Smith, C. (1987). Corporate insurance and the underinvestment problem, Journal of Risk and Insurance. 45-54. Retrieved from http://www.jstor.org/stable/252881

Mian, S. (1996). Evidence on corporate hedging policy. Journal of Financial and Quantitative Analysis, 31(3), 419-439. https://doi.org/10.2307/2331399.

Miciuła, I. (2015). Financial innovations on the currency market as new instruments to risk management, Journal of International Studies, 8(1), 138-149. doi: 10.14254/2071-8330.2015/8-1/12.

Minton, B. A., \& Schrand, C. (1999). The impact of cash flow volatility on discretionary investment and the cost of debt and equity financing. Journal of Financial Economics, 54(3), 423-460. Retrieved from http://www.sciencedirect.com/science/article/pii/S0304-405X(99)00042-2

Myers, G. (1996). The alternative Insurance Market: A Primer, White Paper, Munich Re/America Re, 30 June.

Nance, D. R., Smith, C. W., \& Jr. Smithson, C. W. (1993). On the determinants of corporate hedging, Journal of Finance 48(1), 267-284. doi: 10.2307/2328889.

Pagach, D., \& Warr, R. (2011). The Characteristics of Firms that Hire Chief Risk Officers, The Journal of Risk and Insurance 78 (1), 185-211. Retrieved from https://doi.org/10.1111/j.1539-6975.2010.01378.x

Paape, L., \& Speklé, R. F. (2012). The adoption and design of enterprise risk management practices: An empirical study. European Accounting Review, 21(3), 533-564. Retrieved from https://doi.org/10.1080/09638180.2012.661937.

Peace, Ch. (2008). Captive insurance companies in New Zealand, Working Paper, New Zealand Captive Insurance Association, April 2008, Auckland.

Perera, J., \& J. Holsomback. 2005. An integrated risk management tool and process. Paper presented at the Aerospace Conference IEEE, Big Sky, MT, USA, 5-12 March 2005. 
Punter, A. (2000). New solutions for the financing of risk. Insurance Research and Practice, 15(2), 28-39.

Rosa de la, S. (2006). Board influences cultivating the best board. Retrieved fromhttps://www.highbeam.com/doc/1P3-1141292011.html.

Sigma. (2003). The picture of art. Sigma 1/2003. Retrieved from http://www.swissre.com.

Smith, C. W., \& Stulz, R. M. (1985). The determinants of firms hedging policies. The Journal of Financial and Quantitative Analysis 20(4), 391-405. doi: 10.2307/2330757.

Sprčić, M. D, \& Šević, Ž. (2012). Determinants of Hedging Decisions in Croatian and Slovenian large non-financial companies, Research in International Business and Finance 26 (1), 1-25. doi:10.1016/j.ribaf.2011.05.001.

Stanisz, A. (2007). Przystępny kurs statystyki z zastosowaniem Statistica PL na przykładach z medycyny. Tom III Analizy wielowymiarowe [An affordable statistics course using Statistica PL on the examples of medicine. Volume III - Multivariate analysis]. Krakow: StatSoft.

Stulz, R. (1984). Optimal Hedging Policies, The Journal of Financial and Quantitative Analysis 19(2), 127-140. Retrieved from https://doi.org/10.2307/2330894.

Xianbo, Z., Bon-Gang, H., \& Sui Pheng, L. (2012). Implementing Enterprise Risk Management in a Chinese construction firm based in Singapore. Paper presented at 2012 Global Challenges in Construction Industry, Sri Lanka.

Yazid, A. S., Rizal R. A., \& Hussin, M. R. (2012). Determinants of enterprise risk management (ERM): A proposed framework for Malaysian public listed companies, International Business Research, 5(1), 80. doi:10.5539/ibr.v5n1p80. 